\title{
Hope and Despair at the time of Pandemic
}

\author{
Simin Davoudi and Emma Ormerod
}

\begin{abstract}
At the time when lives and livelihoods are lost, streets are eerily empty, shops are shuttered, schools are closed, cities are locked down, people are isolated from their loved ones, and the spread of Coronavirus is spiralling the world into multiple inter-connected crises, many people are searching for hope in the midst of despair. What is hope, where can we find it, and is hope a social force for change? In this Viewpoint we aim to address these questions and present an account of despair whose roots, we argue, go deeper than the current pandemic and its tragic consequences.
\end{abstract}

\section{Introduction}

"It was the best of times, it was the worst of times [...], it was the season of Light, it was the season of Darkness, it was the spring of hope, it was the winter of despair” (Dickens, $1859,1)$.

With these words, Charles Dickens opens his most political novel, A Tale of Two Cities. Two hundred years later, we cannot but agree that, "In short, the period was [...] like the present period" (Dickens, 1859,1) when hope and despair are inescapably entangled in the unfolding of a global pandemic. At the time when, lives and livelihoods are lost, streets are eerily empty, shops are shuttered, schools are closed, cities are locked down, people are isolated from their loved ones, and the spread of COVID-19 virus is spiralling the world into multiple inter-connected crises, many of us are searching for what Rebecca Solnit (2004) calls 'hope in the dark'. But, what is hope, where can we find it, and is hope a social force for change? We will return to these questions after a brief account of despair whose roots go deeper than the current pandemic and its tragic consequences. 


\section{The worst of times}

On 11 March 2020, the World Health Organization declared the Covid-19 pandemic, stressing that, 'we're in this together' (WHO, 2020). The trope, which is often elevated at the time of crisis, evokes different emotions and serves different purposes. On the one hand, it is an expression of solidarity and a call for global cooperation. On the other hand, it is an invocation of the parity of sufferings and sacrifices. In the context of the pandemic, it is used to suggest that the virus does not discriminate and can affect porters and cleaners as well as princes and prime ministers. However, this narrative overlooks the profoundly unequal health, social and economic impacts of the pandemic. More importantly, unlike the virus itself, which is novel and unknown, its uneven health, social and economic impacts are neither new, nor unexpected. They mirror the inequalities which have been on the rise in the last few decades and particularly since 2010 in the UK. The date is important. It marks the UK government's forefront position on austerity and the introduction of a series of ideologically-driven policies that exacerbated social inequalities and reduced the capacity of the frontline sectors to respond more effectively to the current crises. A notable example is a decade of underfunding in health and social care. The latter has faced major budget cuts and the former has been denied of funding that is needed for the rising demands on its services.

Contrary to its framing as an economic, and even moral, necessity, austerity was a political choice, aimed at, among other things, radical restructurings of the welfare system and public service delivery. Faced with the 2008 financial crisis and growing budget deficit (partly due to the bail out of the banks), the UK government chose to cut public expenditure instead of, for example, raising the level of corporate taxation. Hence, at the same time that the UK economy grew by $5 \%$ (2012 to 2018), public spending for low income households dropped by 44\% (HRW, 2019,14). Throughout the austerity period, the rich have been getting richer and the poor poorer. In 2017/2018, 44\% of total disposable household income went to the top $20 \%$ of high-income households, while 5\% went to the bottom 20\%. The pre-Covid projection for 2020/2021 showed a further widening of income inequalities (McGuiness and Harari, 2019,14). The period between 2010 and 2018 saw a rise in the number of: children in 'absolute poverty' (DWP, 2018,8), foodbank users, homeless people (Shelter, 2019), and precarious and low-paid jobs. There is also 
a spatial dimension to the unequal effects of austerity. Some of the poorest cities and regions have been hit hardest due to severe cuts to their budget for public spending. These same areas often have a concentration of socially disadvantaged people who are heavily reliant on the public sector for both jobs and social services (Davoudi, et al., in press).

Nonetheless, the government deployed the trope of 'we're all in this together' (NewStatesman, 2012) to justify its austerity politics. The claim was a fallacy then and is a fallacy now. Although it conjures up a sense of social solidarity, it is often used to masque the unequal exposure to, and impacts of, the crises on different people and places, which are becoming increasingly evident from the government's official statistics. Mortality rates are higher among older people, men, ethnic minorities, and those with underlying health conditions. The top occupations to be affected by Covid-19 are so-called 'low skilled elementary positions' and 'caring, leisure and other services' while the largest cluster of deaths is in care homes (ONS, 2020). Perhaps, more socially alarming evidence shows that the rate of deaths involving Covid-19 is more than twice as high in the most deprived areas compared with the least deprived areas in England and Wales (ONS, 2020). This is not surprising because disadvantaged people are more vulnerable to the disease because of their poorer pre-existing health conditions and their limited ability to: self-isolate, work from home, have adequate food, live in spacious houses with gardens, and access health care.

The unequal impacts of the pandemic have been accentuated by the unequal impacts of the measures taken to fight it, notably the lockdown. It is estimated that "low earners are seven times as likely as high earners to have worked in a sector that is now shut down" and they are less able to work from home than high earners (Joyce and Xu, 2020, 2). Further, "women are about one third more likely to work in a sector that is now shut down than men” (Joyce and Xu, 2020, 3). Once again, there is a spatial unevenness, too. For example, the North East region has the lowest level of homeworking of the English regions, and within the region places such as Sunderland and Gateshead, which have been among the hardest hit by austerity measures, have the lowest share of workers in high homeworking sectors (ONS, 2020). That the North East region currently has the highest Covid-related death rates per population in England, with Sunderland and Gateshead having the highest rates in the region (ONS, 2020), therefore, comes as little surprise. Added to 
this sense of despair is that these places and social groups will also bear the brunt of the severe recession that is looming.

The Covid crisis has held up a mirror to neoliberal austerity, revealing the devastating consequences of a decade-long program of welfare reform, cuts in public services - especially health and social care - and undervaluing of key workers. Although the pandemic might have taken us by surprise, its uneven impacts should not have, because the epic tragedy that is unfolding before our eyes represents "the wreckage of a train that has been careening down the track for years” (Roy, 2020).

\section{The best of times?}

In this 'winter of despair' where can we find the 'spring of hope'? A simple answer is, everywhere. Being hopeful about the future is a ubiquitous human emotion. But, if hope turns into fantasy, idle desire, or escapism, it is hardly a force for change. It becomes what Ernst Bloch $(1986,56)$ calls "fraudulent hope", which "is one of the malefactors, even enervators, of the human race", a "booty for swindlers". This is a kind of hope that transfers the present into an always postponed future (Dinerstein, 2015) and, hence, perpetuates the status quo. But, there is another kind of hope that can be transformative. Bloch $(1986,56)$ calls it "concretely genuine hope” which arises from “informed discontent” with the present. It brings the future into the present and enables a break with it (Wrangel, 2014). This kind of hope is harder to find, because it is the hidden and invisible drive behind socio-political calls for change, but it exists in the myriad of praxis-oriented activities in everyday life, in the streets, in the neighbourhoods, in the cities, and in the commons, when various forms of collective actions both challenge the normalisation of the present reality and engage with the reality of what Bloch $(1986,56)$ calls the 'Not-Yet'.

In the midst of the pandemic, a good place to look for hope is the emergence of numerous, bottomup, and self-organized civil society actions that are emerging almost every day. As the crisis is escalating, so is the community spirit. Up and down the country, people are volunteering to work at foodbanks, deliver goods and other services to vulnerable people, help in hospitals and care homes, sew protective clothing, and raise funds for charitable organisations. These activities may 
be seen as examples of civil societies having to step in to close the gap created by decades of austerity and failure of the government to protect frontline workers from the risk of infection. As such they may well be plastering over deep structural cracks. Furthermore, civil society organisations themselves seem to have been co-opted into neoliberal agendas as, under austerity, they have had to compete with each other to win government's contracts to deliver what used to be public services (Davoudi, et al., in press). There is, however, more to civil society than charitable works and service delivery, and that is where we may find 'genuine hope'.

To show how hope as a force for change can be sought in unexpected places, we use the example of a seemingly mundane civil society action which nevertheless has captured people's imagination, 'clapping for carers'. Every Thursday at 8.00 O'clock in the evening, people step out of their isolation and join their neighbours - in windows, balconies, and front doors - to clap for those who put their own lives on the line to save the lives of others. Several weeks into lockdown, what started as a simple expression of gratitude turned into something more profound. It became a weekly ritual of performing a sense of belonging, a sense of community, and a sense of doing public good which lasted for ten weeks. Although this example hardly resonates with Alexis de Tocqueville's view of civil society as a form of organised associational life, independent of the state and the market, it has many of the hallmarks of Jürgen Habermas' view of civil society as public sphere. Seen in this way, the synchronised applause can be interpreted as a form of collectivity that is steered by its members through democratically constructed shared meaning which, in this case is, gratitude and appreciation.

Was this emerging civil society action engendered by 'concrete hope'? In other words, did it invoke our "anticipatory consciousness" (Block, 1986, 18) and enable us step out of the present and imagine alternative futures? The answer depends on how we understand the public sphere. If we see it as a static, essentialized and neutral space in which the politics of civil society relations and the tensions surrounding race, gender, class, identity and inclusion are unaccounted for, the answer is no. But, if we think about public sphere as a dynamic, contingent and political space, the answer is maybe, because the collective applause can be seen as the mobilisation of contested public sphere underpinned by transformative hope. The applause can turn into a site of contestation in which people are not passive observers of a universal moral principle (gratitude 
and appreciation), but proactive political actors- with their own visions of the common good- who are contingently engaged in shifting the discourse of what and whom is, or ought to be, valued, as we emerge from the Covid crisis. Hope in this context is that which challenges the narrative of 'there is no alternative' and empowers people to imagine new options in the here and now, rather than in the postponed future. The political force of such hope comes from the possibility "to step out of the moment of hope, to change the present rather than to remain hopeful in it” (Wrangel, 2014, 194).

In the case of clapping, this means channelling the energy and momentum created by it, to secure a raft of changes, including better working conditions for frontline workers, ensuring Living Wage for all, stopping zero-contracts, reversing out-sourcing, re-introducing student bursaries for nurses (removed in 2016), improving junior doctors' contracts (over which they had to strike in 2016), and re-investing in public sector services. There are already signs of 'informed discontent' with the regressive health, economic and social consequences of austerity policies, and of growing recognition that frontline workers “can’t eat applause” (Young and Goodier, 2020). What began with a public outcry against inadequacies of Personal Protective Equipment (PPE) may extend into demands for an alternative socio-economic order which better values key workers and encourages solidarity. Genuine hope as a force for transformation does not lie in feel-good street parties alone or the more negative actions of morally policing social gratitude and appreciation. But if we understand clapping as a civil society action, this moment of rupture has the potential to change the narrative and sustain wider reforms. Questions about the kind of society we want to live in, as we emerge out of this crisis, are now raised in mainstream political debates, and that itself is genuinely hopeful.

\section{References}

Block, E. (1986) The Principle of Hope, Volume 1, Boston, MIT Press.

DWP (Department for Work and Pensions) (2018) Households Below Average Income: An Analysis of the UK Income Distribution: 1994/95-2017/18, https://assets.publishing.service.gov.uk/government/uploads/system/uploads/attachment data/file 
December2019)

Davoudi, S. Steer, M., Shucksmith, M. and Todd, L. (in press) 'Islands of Hope in a Sea of Despair', in M. Steer, S. Davoudi, M. Shucksmith and L. Todd (eds) Hope under Neoliberal Austerity: responses from civil society and civic universities, Bristol, Policy Press

Dickens, C. (1859) A Tale of Two Cities, London, Chapman and Hall.

Dinerstein, A.C. (2015) The politics of autonomy in Latin America. The art of organizing hope. Basingstoke, Palgrave

HRW (Human Rights Watch) (2019), Nothing Left in the Cupboards: Austerity, Welfare Cuts, and the Right to Food in the UK. https://www.hrw.org/report/2019/05/20/nothing-leftcupboards/austerity-welfare-cuts-and-right-food-uk (Accessed 12 December 2019)

Joyce, R. and Xu, X. (2020) Sector shutdowns during the coronavirus crisis: which workers are most exposed? Institute of Fiscal Studies. https://www.ifs.org.uk/publications/14791 (Accessed 15 May 2020)

McGuiness, F and Harari, D. (2019) Income inequalities in the UK, House of Commons Briefing Paper 7484. https://commonslibrary.parliament.uk/research-briefings/cbp-7484/ (Accessed 15 May 2020)

NewStatesman (2012) George Osborne’s speech to the Conservative conference: full text, 8 October. https:/www.newstatesman.com/blogs/politics/2012/10/george-osbornes-speechconservative-conference-full-text (Accessed 15 May 2020)

ONS (Office of National Statistics) (2020) Coronavirus (COVID-19), https://www.ons.gov.uk/peoplepopulationandcommunity/healthandsocialcare/conditionsanddisea ses (Accessed 15 May 2020) 
Roy, A. (2020) 'How coronavirus threatens India', The Financial Times, 3 April https:/www.ft.com/content/10d8f5e8-74eb-11ea-95fe-fcd274e920ca (Accessed 15 May /2020)

Shelter (2019) This is England: A Picture of Homelessness in 2019, 18 December. https://england.shelter.org.uk/media/press_releases/articles/280,000_people_in_england_are_ho meless, with thousands more at risk (Accessed 10 April 2020)

Solnit, R. (2004) Hope in the Dark, Untold Histories, Wild Possibilities, New York, Nation Book.

WHO (World Health Organisation) (2020) WHO Director-General's opening remarks at the media briefing on COVID-19, 11 March. https://www.who.int/dg/speeches/detail/who-director-generals-opening-remarks-at-the-media-briefing-on-covid-19---11-march-2020 (Accessed 15 May 2020)

Wrangel, C. (2014) 'Hope in a time of catastrophe? Resilience and the future in bare life', Resilience: International Policies, Practices and Discourses, 2, 183-194

Young, T. and Goodier, M. (2020) “"You can’t eat applause": why the coronavirus crisis poses dilemmas for trade unions', NewStatesman, $30 \quad$ April. https://www.newstatesman.com/politics/uk/2020/04/coronavirus-key-workers-pay-conditionsunions-NHS-front-line-applause (Accessed 15 May 2020) 